\title{
Isolasi Glukosamin dari Limbah Cangkang Rajungan Portunus pelagicus (Linnaeus,1758) (Malacostraca:Portunidae) dengan Hidrolisis Asam Klorida
}

\author{
Miftahul Akhyar Ghofari*, Ali Ridlo, Rini Pramesti \\ Departemen IImu Kelautan, Fakultas Perikanan dan IImu Kelautan, Universitas Diponegoro \\ JI. Prof.H.Soedarto S.H, Tembalang, Semarang, Jawa Tengah 50275 Indonesia \\ ${ }^{*}$ Corresponding author, e-mail : Akhyar.gho@gmail.com
}

\begin{abstract}
ABSTRAK: Glukosamin merupakan monomer dari kitosan yang dapat diperoleh dari limbah cangkang rajungan $P$. pelagicus. Glukosamin dibutuhkan dalam pembentukan dan perbaikan tulang rawan dan jaringan tubuh lainnya. Penelitian ini bertujuan untuk mengetahui karakteristik glukosamin dari limbah cangkang rajungan. Proses isolasi kitosan rajungan terdiri dari deproteinasi dengan $\mathrm{NaOH} 3 \mathrm{~N}$, demineralisasi dengan $\mathrm{HCl} 1 \mathrm{~N}$, dan deasetilasi dengan $\mathrm{NaOH}$ $50 \%$. Kitosan yang diperoleh dianalisis karakteristik dan derajat deasetilasinya, selanjutnya kitosan dihidrolisis secara kimia dengan larutan $\mathrm{HCl} 20 \%$ pada suhu kamar selama 4 jam. Glukosamin yang dihasilkan dihitung rendemen, loss on drying (LoD), tingkat kelarutan dan derajat deasetilasinya. Hasil penelitian menunjukan rendemen kitosan cangkang rajungan adalah $11,3 \%$, berwarna putih, tidak berbau, kadar air 9,2\%, kadar abu $5,4 \%$, dan derajat deasetilisasi $90,8 \%$. Rendemen glukosamin sebesar $8,6 \%$, dengan nilai Loss on Drying 1,3\%, kelarutan sebesar $72 \%$ dan derajat deasetilisasi sebesar $96,95 \%$. Spektra infrared menunjukan adanya gugus $-\mathrm{NH},-\mathrm{OH},-\mathrm{CH}$ dan $-\mathrm{C}=\mathrm{O}$ yang sesuai dengan yang terdapat pada glukosamin.
\end{abstract}

Kata Kunci : Glukosamin, P pelagicus, Hidrolisis, asam klorida.

\section{Glucosamine Isolation from Portunus pelagicus, Linnaeus, 1758 (Malacostraca:Portunidae) Shell waste With Chemical Hydrolysis Method}

ABSTRACT: Glucosamine is a monomer from chitosan which can be obtained from small crab shell (P pelagicus) waste. Glucosamine is needed in the formation and repair of cartilage and other body tissues. This study aims to determine the characteristics of glucosamine from small crab shell waste. The process of isolating chitosan from small crab shells consisted of deproteination with $3 \mathrm{~N}$ $\mathrm{NaOH}$, demineralization with $1 \mathrm{~N} \mathrm{HCl}$, and deacetylation with $50 \% \mathrm{NaOH}$. The chitosan obtained was analyzed its characteristics and degrees of deacetylation, then chitosan was chemically hydrolyzed with $20 \% \mathrm{HCl}$ solution at room temperature for 4 hours. The resulting glucosamine is then calculated yield, loss on drying (LoD), solubility level and degree of deacetylation. The results showed that the yield of chitosan crab shells was $11.3 \%$, white, odorless, $9.2 \%$ moisture content, $5.4 \%$ ash content, and $90.8 \%$ deacetylation rate. Glucosamine yield was $8.6 \%$, with a Loss on Drying value of $1.3 \%$, solubility of $72 \%$ and the degree of deacetylation of $96.95 \%$. Infrared spectra show the presence of $-\mathrm{NH},-\mathrm{OH},-\mathrm{CH}$ and $-\mathrm{C}=\mathrm{O}$ groups that match those found in glucosamine.

Keywords: Glucosamine, P pelagicus, Hydrolysis, hydrochloric acid.

\section{PENDAHULUAN}

Indonesia berpotensi dibidang angroindustri sebagai penghasil biota laut seperti rajungan. Rajungan ( $P$ pelagicus) merupakan komoditas sektor perikanan yang dijual dalam bentuk kemasan. Tahun 2016 ekspor rajungan hasil pengalengan mencapai 19,4 ribu ton (APRI 2017). Jika diasumsikan $\pm 50 \%$ dari total berat adalah limbah maka berat limbah mencapai \pm 9 ribu ton. Pemanfaatan limbah cangkang rajungan yang belum maksimal menimbulkan penumpukan limbah di tepi pantai dan bau busuk bercampur amis. Salah satu alternatif pemanfaatan limbah cangkang rajungan agar memiliki nilai dan daya guna adalah dengan mengubah menjadi produk yang 
bernilai ekonomis tinggi seperti kitosan dan glukosamin, yang dapat dijadikan berbagai bahan industri.

Glukosamin $\mathrm{C}_{6} \mathrm{H}_{13} \mathrm{NO}_{5}$ merupakan monomer kitosan yang terdapat pada cangkang rajungan, berfungsi sebagai prekursor dalam biosintesis protein glikosilat dan lipid untuk memproduksi cairan synovia,I sebagai pelumas pada tulang rawan (Syukron, et al., 2016). Pemanfaatan limbah cangkang rajungan menjadi glukosamin terdiri dari dua tahap yaitu proses pembuatan kitosan dilanjutkan hidrolisis kitosan menjadi glukosamin. Proses pembuatan kitosan dilakukan melalui beberapa tahap yaitu deproteinasi, demineralisasi, dan deasetilasi. Proses pembuatan glukosamin dilakukan dengan hidrolisis kimiawi dengan ion hidrogen sebagai katalis (Wanichpongpan \& Attasat, 2016).

Hidrolisis kitosan menjadi glukosamin dapat dilakukan dengan beberapa metode antara lain hidrolisis kimiawi, enzimatik, fermentasi dan variasi campuran dari beberapa metode tersebut (Cahyono et. al., 2014). Produksi glukosamin secara enzimatik lebih ramah lingkungan, namun memiliki keterbatasan pada stabilitas enzim dan biaya ekstraksi enzim yang cukup mahal. Produksi glukosamin secara kimiawi memiliki keunggulan, yaitu bahan yang dibutuhkan cenderung lebih mudah diperoleh, produksi glukosamin relatif cepat dan produksi dapat dilakukan dalam skala besar. Kelemahan hidrolisis secara kimiawi adalah bahan bahan kimia yang digunakan dapat mencemari lingkungan (Dutta et al., 2004).

Metode hidrolisis glukosamin secara kimiawi dengan menggunakan asam kuat seperti $\mathrm{HCl}$ dan $\mathrm{H}_{2} \mathrm{SO}_{4}$ menghasilkan rendemen yang lebih banyak (Mojarrad et al., 2007). Beberapa jenis asam seperti $\mathrm{HCl}$ dan $\mathrm{H}_{2} \mathrm{SO}_{4}$ dengan berbagai konsentrasi telah digunakan untuk mengekstraksi glukosamin dari kitin. Pengolahan glukosamin hidroklorida dari kitin dilakukan melalui reaksi hidrolisis sederhana. Selama reaksi tersebut, kitin akan melewati proses deasetilasi dan depolimerisasi untuk menjadi glukosamin hidrolorida sebagai hasil dari perendaman didalam larutan asam hidroklorida (Mojarrad et al., 2007).

\section{MATERI DAN METODE}

Materi pada penelitian ini adalah limbah cangkang rajungan (Portunus pelagicus) yang di ambil di Desa Gegunung Kabupaten Rembang. Limbah cangkang rajungan dicuci dan dipanaskan pada suhu $60{ }^{\circ} \mathrm{C}$ selama 10 menit, kemudian di jemur dibawah sinar matahari selama 3 hari, selanjutnya dihaluskan dan diayak dengan ukuran 100 mesh / 0,149 mm.

Demineralisasi dilakukan dengan memanaskan bubuk cangkang rajungan sebanyak $290 \mathrm{~g}$ dengan campuran $\mathrm{HCl} 1 \mathrm{~N}$ sebanyak 2 liter (1:7) pada suhu $90{ }^{\circ} \mathrm{C}$ selama 1 jam, kemudian disaring dan di ambil residunya. Residu dicuci dengan aquadest hingga $\mathrm{pH}$ netral, selanjutnya dipanaskan pada suhu $70{ }^{\circ} \mathrm{C}$ selama 24 jam. Serbuk hasil demineralisasi dideproteinisasi menggunakan $\mathrm{NaOH} 3 \mathrm{~N}$ sebanyak 1,6 I $(1: 10 \mathrm{~g} / \mathrm{ml})$ pada suhu $90{ }^{\circ} \mathrm{C}$ selama 1 jam, setelah itu disaring, residu dicuci kembali hingga $\mathrm{pH}$ netral dan dipanaskan pada suhu $70{ }^{\circ} \mathrm{C}$ selama 24 jam. Setelah itu residu direndam dalam larutan $\mathrm{NaOH} 50 \%$ sebanyak 1,7 liter (1:20 b/v) dan dipanaskan pada suhu $100{ }^{\circ} \mathrm{C}$ selama 2 jam sambil diaduk, kemudian dicuci dengan air sampai $\mathrm{pH}$ netral, dijemur sehingga diperoleh kitosan. Sebanyak 4 gr kitosan direndam $\mathrm{HCl} 20 \%$ sebanyak $36 \mathrm{ml}$ $(1: 9 \mathrm{~b} / \mathrm{v})$. Larutan diaduk pada suhu ruangan selama 6 jam, selanjutnya larutan diendapkan, kemudian disaring menggunakan kain kasa. Disaring dipanaskan pada suhu $70{ }^{\circ} \mathrm{C}$ selama 4 jam. Glukosamin dianalisis rendemen, warna, kadar air, kadar abu, mengacu pada AOAC (2005). Analisis infrared dilakukan menurut (Swann \& Patwardhan 2011). Less On Drying mengacu pada Ileleji et al. (2010).

\section{HASIL DAN PEMBAHASAN}

Cangkang rajungan yang diperoleh berwarna putih kecoklatan kemudian dihaluskan didemineralisasi, dideproteinasi dan dideasetilisasi yang menghasilkan kitosan. Kualitas kitosan dari limbah cangkang rajungan (Tabel 1). Kitosan yang diperoleh berwarna putih kecoklatan dimana sesuai standar GRAS (2012), namun kitosan yang baik umumnya berwarna putih. Warna kecoklatan pada kitosan disebabkan karena pada proses demineralisasi dan deproteinasi masih terdapat bahan - bahan organik yang belum hilang secara maksimal. 
Kitosan yang diperoleh pada penelitian ini sebesar $33 \mathrm{~g}$ atau $11,3 \%$, lebih rendah dari penelitian Mohanasrinivasan et al. (2013) 17\%; Sari dan Abidin (2015) 46,30 \%. Rendemen kitosan dipengaruhi berbagai proses pada saat pembuatanya, seperti konsentrasi $\mathrm{HCl}$ saat demineralisasi, waktu reaksi demineralisasi deproteinasi dan deasetilisasi. Konsentrasi $\mathrm{HCl}$ yang tinggi akan meningkatkan jumlah mineral atau protein yang terlepas. Temperatur yang tinggi akan mempercepat laju reaksi, hal ini dikarenakan temperatur yang tinggi dapat menyebabkan rantai molekul pada kitosan terdepolimerisasi dan mengakibatkan terjadinya penurunan berat molekul dan rendemen kitosan (Patria, 2013).

Kadar air kitosan pada penelitian ini sebesar 9,2\%. Nilai kadar air tersebut masih berada didalam standar mutu kadar air kitosan yaitu $<10 \%$. Air merupakan parameter penting dalam bahan, karena dapat mempengaruhi tekstur dan penampakkan. Kadar air mempunyai peranan penting dalam menentukan daya awet bahan, karena dapat mempengaruhi sifat fisik, perubahan fisik, perubahan mikrobiologi dan perubahan enzimatis (Buckle, 1987). Menurut Nielsen (1998), penentuan kadar air suatu bahan sangat tergantung pada tipe oven yang digunakan, kondisi dalam oven, suhu, dan waktu pengeringan.

Kadar abu kitosan (5,4\%) lebih besar jika dibandingkan dengan standar EFSA (2010) $\leq 3 \%$ dan GRAS $(2012) \leq 0,05 \%$, hal menunjukkan bahwa proses reaksi demineralisasi, deproteinisasi dan deastilasi belum dapat mengurangi komponen senyawa anorganik secara maksimal. Jumlah dan komposisi abu dalam mineral tergantung pada jenis bahan. Kadar abu bisa digunakan sebagai indikasi kandungan mineral dalam sampel.

Tabel 1. Karakteristik Kitosan dari Limbah Cangkang Rajungan

\begin{tabular}{llll}
\hline Spesifikasi & Hasil & EFSA 2010 & GRAS 2012 \\
\hline Rendemen & $11,3 \%$ & - & - \\
Warna & Putih Kecoklatan & - & White to off white \\
& Tidak Berbau & - & powder \\
Bau & 100 mesh & - & $18-120$ Mesh \\
Ukuran & $9,2 \%$ & $\leq 10 \%$ & $\leq 10 \%$ \\
Kadar Air & $5,4 \%$ & $\leq 3$ & $\leq 0,5 \%$ \\
Kadar Abu & $90,8 \%$ & $\geq 90 \%$ & $75-95 \%$ \\
Derajat Deasetilisasi & & & \\
\hline
\end{tabular}

Keterangan : EFSA (European Food Safety Authority); GRAS (General recognition of safety)

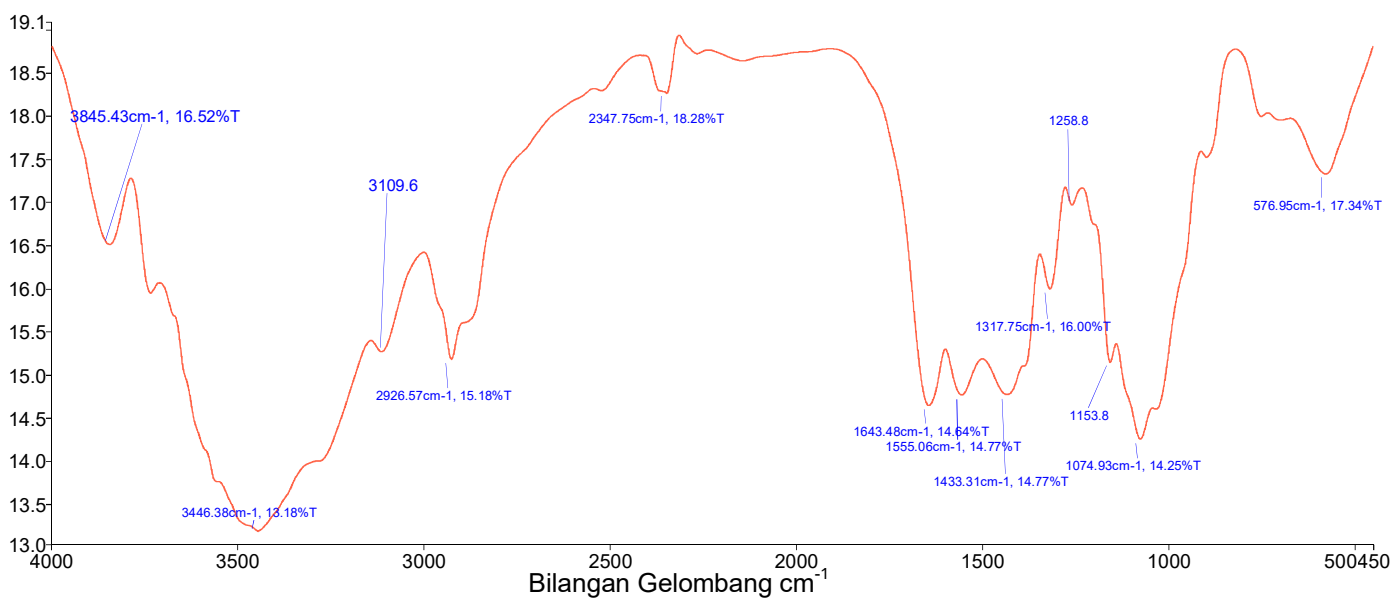

Gambar 2. Spektra infrared kitosan dari limbah cangkang rajungan. 
Spektra infrared kitosan (Gambar 2) diduga menunjukan adanya puncak puncak yang sesuai dengan kitosan yaitu mengandung gugus fungsi $\mathrm{O}-\mathrm{H}, \mathrm{C}-\mathrm{H}, \mathrm{C}=\mathrm{O}$ dan $\mathrm{N}-\mathrm{H}$ selengkapnya Tabel 2. Derajat deasetilasi kitosan pada penelitian ini sebesar 90,8\%, Penelitian Walke et al. (2014) 75-85\%; Mohanasrinivasan et al. (2013) 74,82\%; Trung dan Phuong (2012) 82,3 $\pm 05 \%$. Derajat deasetilisasi menunjukan tingkat keberhasilan proses deasetilisasi kitosan dari kitin dengan katalis basa. Derajat deasetilasi (DD) merupakan suatu parameter lepasnya gugus asetil dari kitosan. Derajat deasetilasi diketahui dengan perhitungan persentase banyaknya gugus asetil yang hilang dan digantikan dengan $-\mathrm{H}$ saat proses deasetilasi. Erika et al. (2005), menyatakan bahwa semakin tinggi derajat deasetilasi kitosan menunjukkan semakin banyak gugus asetil yang dilepaskan dan semakin banyak gugus amina bebas $\left(-\mathrm{NH}_{2}\right)$ yang terbentuk.

Vibrasi regangan pada bilangan gelombang $1643,48 \mathrm{~cm}^{-1}$ merupakan pita serapan gugus ikatan $\mathrm{C}=\mathrm{O}$ yang menunjukkan adanya gugus amida sekunder, pita serapan pada bilangan gelombang 3446,39 $\mathrm{cm}^{-1}$ merupakan vibrasi pembengkokan gugus $-\mathrm{OH}$ dan gugus $-\mathrm{NH}$. Berdasarkan analisis karakteristik spektrum inframerah, adanya spektrum utama pada daerah panjang gelombang tertentu yang menunjukkan adanya gugus fungsi utama yang mengindikasikan bahwa senyawa hasil reaksi deastilasi dalam penelitian adalah kitosan.

Menurut Benavente (2015) proses hidrolisis melibatkan dua reaksi hidrolisis yang dikatalis asam: ikatan glikosidik (depolimerisasi) dan ikatan $\mathrm{N}$-acetil (deasetilisasi). Sebagian besar degradasi ikatan kitin terjadi selama beberapa menit pertama, dan produk yang terbentuk adalah oligosakarida. Gambar 2. menunjukan mekanisme reaksi yang paling dapat diterima untuk reaksi hidrolisis yang dikatalis oleh asam pada ikatan glikosida dan reaksi hidrolisis yang dikatalis oleh asam pada ikatan $\mathrm{N}$-acetil (Benavente, 2015)

Tabel 2. Gugus fungsi kitosan dari limbah cangkang rajungan berdasarkan spektra FTIR

\begin{tabular}{cc}
\hline Gugus fungsi & Bilangan gelombang $\left(\mathrm{cm}^{-1}\right)$ \\
\hline O-H & 3446,38 (stretching); 1317,75 (bend) \\
$C-H$ non aromatic & 2926,57 \\
$C=O$ karbonil amida & 1643,$48 ; 1074,93$ (stretching) \\
$\mathrm{N}-\mathrm{H}$ amina & 3109,6 (stretching); 1555,06; 1153,8 \\
\hline
\end{tabular}

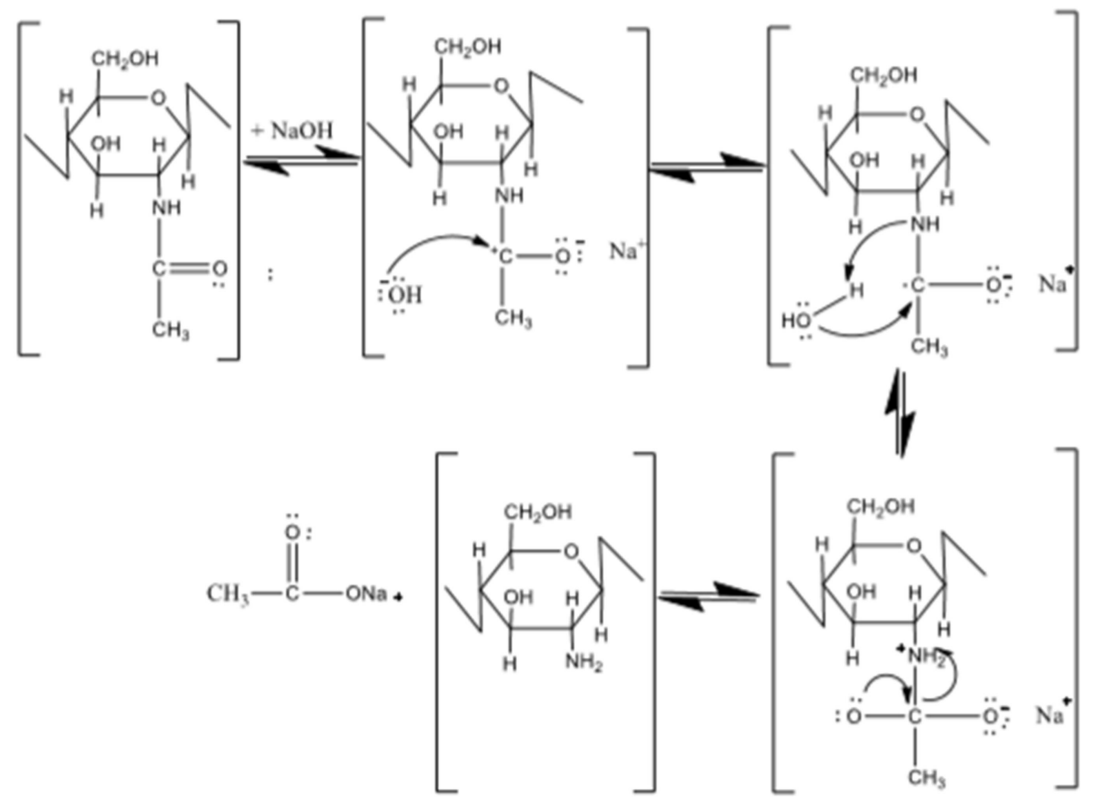

Gambar 3. Reaksi deasetilisiasi pada kitin (Basuki \& Sanjaya, 2009) 
Hasil penelitian tahap 2 berupa glukosamin. Kualitas glukosamin dari hidrolisis kitosan dengan $\mathrm{HCl} 20 \%$ pada suhu ruangan (Tabel 3). Konsentrasi asam yang digunakan penelitian ini sebesar $20 \%$ selama 6 jam tanpa adanya pemanasan, rendemen glukosamina hidroklorida yang dihasilkan sebesar 8,6\% dari berat serbuk cangkang rajungan sedangkan Kraisangsri et al. (2018) $36 \%$; Nurjannah et al. (2016) menghidrolisis dengan $\mathrm{HCl} 27 \%$ pada suhu $90{ }^{\circ} \mathrm{C}$ selama 4 jam menghasilkan rendemen sebesar $18.39 \%$. Banyak faktor yang dapat mempengaruhi jumlah rendemen yang dihasilkan antara lain konsentrasi asam, rasio asam/sampel (v/w), tekanan, waktu (Mojarrad et al., 2007). Menurut Suptijah (2014), konsentrasi asam 8\% dengan penambahan perlakuan dengan tekanan 1 atm telah mampu menghidrolisis glukosamin dengan karakter yang cukup baik. Hal ini terjadi karena adanya faktor tekanan yang diberikan saat hidrolisis. Kombinasi perlakuan antara tekanan dan suhu mempercepat proses depolimerisasi kitosan menjadi glukosamin sehingga waktu pemanasan menjadi lebih singkat dengan konsentrasi asam yang cukup rendah.

Kelarutan gluksamin pada penelitian ini sebesar 72\%. Kralovec \& Barrow (2008), menyatakan glukosamin hidroklorida dapat larut sempurna dalam air. Suatu zat yang larut dengan mudah pada pelarut yang bersuhu rendah mengindikasikan bahwa zat tersebut memiliki tingkat kelarutan yang baik. Hasil penelitian yang diperoleh menunjukkan glukosamin yang diproduksi belum sesuai dengan standar baku yang ditetapkan EFSA (2009) yaitu 90\%. Tingkat kelarutan yang kurang tinggi pada penelitian ini diduga beberapa faktor, salah satunya suhu. Suhu yang digunakan diduga terlalu rendah sehingga belum dapat menghidrolisis kitosan menjadi glukosamin secara sempurna sehingga masih terdapat polimer kitosan yang belum terhidrolisis.

Nilai LoD glukosamin pada penelitian sebesar 1,3\%. (USP, 2006). Derajat deasetilasi glukosamin yang diukur dalam penelitian ini adalah 96,95\% lebih tinggi dibandingkan dengan baku mutu glukosamin standar (Cargill, 2006) yaitu 75-95 \% namun belum memenuhi standar EFSA (2009) sebesar $98 \%$.

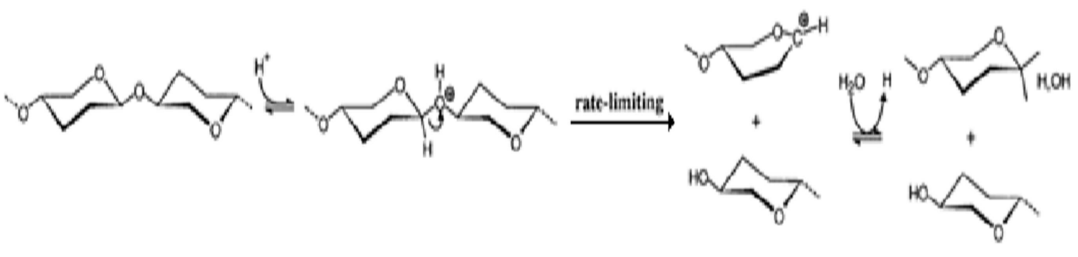

(a)
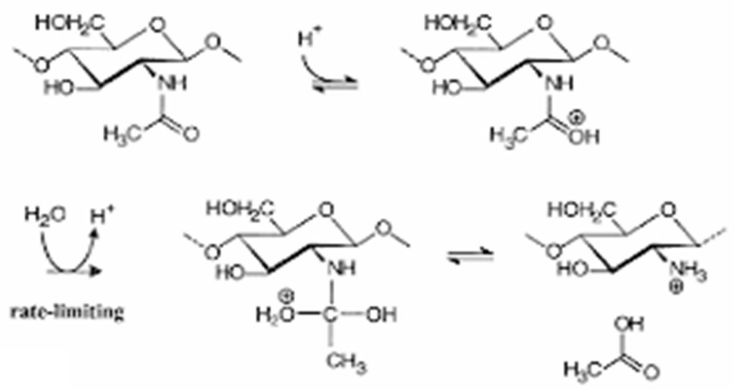

(b)

Gambar 4. Mekanisme reaksi hidrolisis ikatan (a) glikosida pada karbohidrat dan (b) N-acetil dengan asam (Benavante et al., 2015).

Tabel 3. Karakteristik glukosamin dari limbah cangkang rajungan

\begin{tabular}{lll}
\hline Karakteristik & Hasil Analisis & Standar EFSA \\
\hline Rendemen & $8,6 \%$ & - \\
Kelarutan & $72 \%$ & $90 \%$ \\
LoD & $1,3 \%$ & $1 \%$ \\
Derajat Deasetilisasi & $96,95 \%$ & $98 \%$ \\
\hline
\end{tabular}




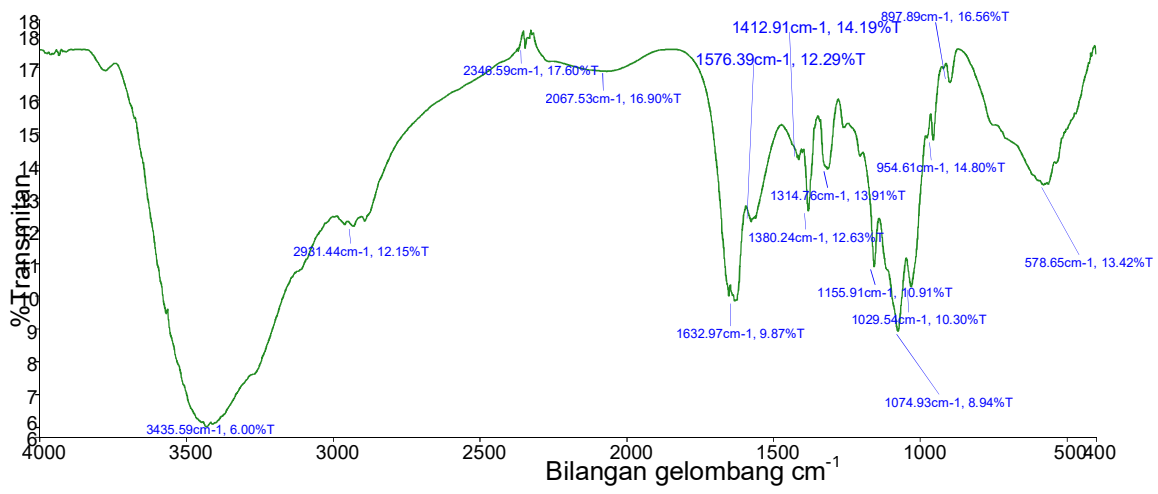

Gambar 5. Spektra infrared glukosamin dari limbah cangkang rajungan

Tabel 4. Gugus Fungsi Glukosamin Berdasarkan Spektra FTIR.

\begin{tabular}{ll}
\hline Gugus Fungsi & Bilangan gelombang $\left(\mathrm{cm}^{-1}\right)$ \\
\hline O-H & 3446,38 (Stretch); 1380,24 (Bend) \\
N-H & 1632,97 ( bend); 1576,39 (amina sekunder) \\
C-H Non aromatic & 2931,44 (Stretch); 897,89 \\
C-O Stretch, & 1155,91 \\
\hline
\end{tabular}

Spektra infrared Gambar 4 menunjukan adanya gugus $\mathrm{O}-\mathrm{H}, \mathrm{N}-\mathrm{H}, \mathrm{C}-\mathrm{H}$ dan $\mathrm{C}-\mathrm{O}$ yang dibuktikan dengan puncak pada bilangan gelombang 3446.38, (Tabel 4). Menurut Cahyono et.al 2015, glukosamin mengandung gugus $\mathrm{O}-\mathrm{H}$ dan $\mathrm{N}-\mathrm{H}$ pada $3450-3350$ jika bilangan gelombang mendekati 3450 menunjukan hasil masih berbentuk polimer dan 3350 sudah berbentuk monomer.

Spektrum infrared menunjukan proses deasetilisasi, karena bilangan gelombang pada $\sim 1700 \mathrm{~cm}^{-1}$ yang menunjukan $\mathrm{C}=\mathrm{O}$ telah menghilang (Mojarrad, 2007). Derajat deasetilisasi glukosamin yang dihasilkan lebih besar dibandingkan dengan kitosan. Hal ini diduga saat proses hidrolisis ikatan glikosida dengan $\mathrm{HCl} 20 \%$, terjadi juga proses pemutusan ikatan amida. Asam berfungsi sebagai katalis yang membantu kerja air dalam proses hidrolisis ikatan glikosida, Semakin tinggi konsentrasi asam yang digunakan sampai pada konsentrasi yang optimum maka hasil akan bertambah besar (Mardina et. al., 2014). Banyaknya hasil reaksi juga dipengaruhi oleh lamanya waktu reaksi, suhu, dan tekanan. Rendemen akan semakin meningkat dengan semakin lamanya waktu reaksi sampai pada waktu optimum (Groggins, 1958).

Glukosamin yang dihasilkan terlihat masih belum murni, sehingga ada potensi spektum FTIR yang dihasilkan juga terinterferensi dengan adanya gugus - gugus pengganggu. Pita serapan pada glukosamin menunjukan puncak serapan $1576,39 \mathrm{~cm}^{-1}$ yang menunjukan adanya amina sekunder pada glukosamin dari limbah cangkang rajungan. Ikatan $\mathrm{N}-\mathrm{H}$ Stretching tidak terlihat, hal ini diduga ditutupi oleh peak O-H Stretching yang melebar.

\section{KESIMPULAN}

Berdasarkan hasil penelitian dapat disimpulkan bahwa glukosamin dapat diperoleh dari limbah cangkang rajungan dengan cara hidrolisis kimiawi menggunakan $\mathrm{HCl} 20 \%$ pada suhu kamar. Karakteristik glukosamin yang diperoleh yaitu; rendemen 8,6\%, derajat deasetilisasi 96,95 $\%$, kelarutan $72 \%$, Less on Drying 1,3\%.

\section{DAFTAR PUSTAKA}

AOAC [Association of Official Analytical and Chemistry]. 2005. Officials Methods of Analysis. 18th Ed. Marylan: Association of Official Analytical and Chemistry Inc.

Asosiasi Pengelolaan Rajungan Indonesia Kab. Pemalang. 2017. Pemalang Bertekad Pelihara Laut Pertahankan Kelestarian Rajungan. Diakses dari https://babel.antaranews.com 
/berita/54269/pemalang-bertekad-pelihara-laut-pertahankan-kelestarian-rajungan. Tanggal 20 April 2019 pukul 21.00 WIB.

Benavente, M., Arias, S. \& Morena, L., 2015. Production of Glucosamine Hydrochloride from Crustacean Shell, Journal of Pharmacy and Pharmacology, 3:20-26.

Buckle, K.A.1987,IImu pangan. Universitas Indonesia Press. Jakarta

Cahyono, E., Suptijah, P. and Wientarsih, I., 2014. Development of a pressurized hydrolysis method for producing glucosamine. Asian Journal of Agriculture and Food Sciences

Cargill. 2006, Application for the Approval of the use REGENASURE $®$ Non Shellfish Glucosamine Hydrochloride from Aspergillus Niger (RGHAN) for use in Certain Foods Products under Regulation (EC) No 258/97 for the European Parliament and of the Council of 27 January 1997 Concerning Novel foods and Novel Food Ingredients, Eddyville, USA: Cargill Incorporated.

Dutta, P., Dutta, J. \& Tripathi, V., 2004. Chitin and chitosan: chemistry, properties and applications. Journal of Scientific \& Industrial Research, 63:20-31.

Erika, I., Rojas, D., Waldo, M., Arguelles, M., Inocencio, H.C., Javier, H., Jaime, L.M. \& Francisco, M.G., 2005, Determination Of Chitin and Protein Contents During The Isolation of Chitin from Shrimp Waste. Macromolecular Bioscience, 6:340-347.

European Food Safety Authority, 2009, Scientific Opinion on the Substantiation of a Health Claim Related to Glucosamine Hydrochloride and Reduced Rate of Cartilage Degeneration and Reduced risk of development of osteoarthritis pursuant. European Food Safety Authority, 7(10):1-9.

European Food Safety Authority, 2010, Scientific opinion on the safety of chitin-glucan as a novel food ingredient, European Food Safety Authority, 8(7):1-17.

GRAS (General recognition of safety), 2012, Chitoclear $®$ Shrimp-Derived Chitosan: Food Usage Conditions For General Recognition Of Safety, Iceland (IL): GRAS

Groggins, P.H., 1958, Unit Processes in Organic Synthesis, 5th ed., p. 775-777. McGraw-Hill Book Company. New York

Ileleji, K.E., Gracia, A.A., Kingsly, A.R.P. \& Clemetson, C.L., 2010, Comparison of Standard Moisture Loss on Drying Methods for Determination of Moisture Content of Corn Distillers Dried Drains with Solubles. Journal of Association of Official Analytical Chemists International. 93(3):825-831

Kraisangsri, J., Nalinanon, S., Riebroy, S., Yarnpakdee, S. \& Ganesan, P. 2018. Physicochemical characteristics of glucosamine from blue swimming crab (Portunus pelagicus) shell prepared by acid hydrolysis. Walailak Journal of Science and Technology, 15: 869-877

Kralovec, J.A., Barrow, J.C., 2008, Marine Neutraceticals and Functional Foods, London. New York: CRC Press. .

Mardina, P., Phratama, H.A. \& Hayati, D.M., 2014, Pengaruh Waktu Hidrolisis dan Konsentrasi Katalisator Asam Sulfat Terhadap Sintesis Furfural dari Jerami Padi. Konversi, 3:1-8.

Mohanasrinivasan, V., Mishra, M., Paliwal, J.S., Singh, S.K., Selvarajan, E., Suganthi, V., \& Devi C.S., 2013, Studies on Heavy Metal Removal Efficiency and Antibacterial Activity of Chitosan Prepared From Shrimp Shell Waste, Journal Biotechnology, 1(3):01-09

Mojarrad, J.S., Nemati, M., Valizadeh, H., Ansarin, M. \& Bourbour, S.,2007, Preparation of Glucosamine from Exoskeleton of Shrimp and Predicting Production Yield by Response Surface Methodology, Journal of Agricultural Food Chemistry, 55(6): 2246-2250.

Nielsen, S.S., 1998, Food Analysis Second Edition, Aspen Publisher Inc. Maryland.

Nurjannah, A., Darmanto, D. \& Wijayanti, I., 2016. Optimization Making Glucosamine Hydrochloride $(\mathrm{HCl} \mathrm{GlcN})$ of Crab Shell Waste through Chemical Hydrolysis. Jurnal Pengolahan Hasil Perikanan Indonesia, 19(1):26-35. DOI: 10.17844/jphpi.2016.19.1.26.

Patria, A, 2013, Production And Characterization Of Chitosan From Shrimp Shells Waste. International Journal of The Bioflux Society, 6(4):339-344.

Sari, D.P. \& Abdiani, I.M. 2015, Pemanfaatan Kulit Udang dan Cangkang Kepiting sebagai Bahan Baku Kitosan. Jurnal Harpondon Borneo, 8(2):142-147.

Suptijah, P., Bustami, I. \& Ernawati. 2014, Pemanfaatan Limbah Krustasea dalam Pembuatan Glukosamin Hidroklorida (Glcn Hcl) dengan Metode Autoklaf, Jurnal Teknologi Perikanan dan Kelautan, 5(2):171-179. 
Swann, G.E.A., Patwardhan, S.V., 2011, Application of Fourier Transform Infrared Spectroscopy (FTIR) for Assessing Biogenic Silica Sample Purity in Geochemical Analyses and Palaeoenvironmental Research. Journal Climate of the Past, 10(7):65-74.

Syukron, F., Karnila, R. \& Hasan, B., 2016, Karakteristik Glukosamin Hidroklorida ( Hcl Glcn) dari Kitin dan Kepiting Chitosan Biru Kolam (Portunus Pelagicus). Berkala Perikanan Terubuk, 44(2):22-35.

Trung, T.S. \& Phuong, P.T.D., 2012, Bioactive Compounds from by-Products of Shrimp Processing Industry in Vietnam, Journal of Food and Drug Analysis, 20(1):194-197.

Walke, S., Srivastava, G., Nikalje, M., Doshi, J., Kumar, R., Ravetkar, S. \& Doshi, P., 2014, Physicochemical and Functional Characterization of Chitosan Prepared from Shrimp Shells and Investigation of its Antibacterial, Antioxidant and Tetanus Toxoid Entrapment Efficiency, International Journal of Pharmaceutical Sciences Review and Research, 26(2):215-225.

Wanichpongpan, P. \& Attasat, S., 2016, Optimum Conditions for Preparation of Glucosamine Hydrochloride and Glucosamine Sulfate from Shrimp-Shell Chitin. International Journal of Applied Science and Technology, 6;24-29. 